\title{
Workaholism and Consequential Health, Family and Social Issues
}

\author{
S. Subhashini ${ }^{* *}$ and G. Palaniappan ${ }^{2}$ \\ 'Assistant Professor, Department of Management Studies, Annapoorana Engineering College, \\ Salem, Tamil Nadu, India; subhashine81@gmail.com \\ ${ }^{2}$ Associate Professor, Department of Management Studies, Vinayaka Missions Kirupananda \\ Variyar Engineering College, Salem, Tamil Nadu, India; palani.sunn@gmail.com
}

\begin{abstract}
Organizations are getting concerned about the workaholic people, as the managers are facing complexity in terms of managing such work addicted employees. These workaholic employees face greater amount of difficulties both in their work and family life due to their excessive obsession towards work. As a result they face several physical and psychological problems, and at the same time the organizations suffer in terms of productivity. This study aims at focusing on Workaholism and the resulting health, family and social issues among IT Employees, particularly Project and Team Leaders in the selected five cities of Tamil Nadu. The interview schedule was prepared and the data was collected from 118 respondents. The study reveals that the respondents are workaholic and suffer from health, family and social issues.
\end{abstract}

Keywords: Family, Health, Marital Issues, Social Issue, Stress, Workaholism

\section{Introduction}

In today's world, the policy of globalisation is placing heavier demands on the upcoming professionals. The employees are pushed to a situation in which, their maximum efforts and potentials can only be helpful in sustaining their current jobs. This has in turn led to Workaholism. Workaholism is a general tendency among the employees, who compromise their health, family and other pleasures for the sake of their jobs, resulting in social issues. Workaholic people tend to work extra hours and put in extra hard works in their jobs, in order to sustain their jobs.

\section{Review of Literature}

\subsection{Workaholism Correlate with Stress and Health Issues}

Andreassen, Ursin and Eriksen ${ }^{1}$ confirmed a mild association between work stress and workaholism. Spence and
Robbins $^{2}$ asserted that workaholics suffer higher stress than work enthusiasts. Robinson ${ }^{3}$ asserted that higher rate of errors was committed by workaholics. Nespor ${ }^{4}$ exposed the workaholic's efficiency in apportioning the time for different aspects of the work. According to Scott et al., ${ }^{5}$ workaholics strongly feel that amusement in life is unnecessary. Bonebright et al., ${ }^{6}$ have brought to the fore that workaholism does not reconcile the over workload and its adverse consequences. According to Schaufeli et al., ${ }^{7}$ workaholics keep on thinking about work. Taris et al., ${ }^{8}$ conclude that workaholics become emotionally exhausted over time. Kubota et al., ${ }^{9}$ confirmed that workaholic people suffer from diminished sleep quality. According to Schaufeli et al., ${ }^{10}$ and Shimazu and Schaufeli ${ }^{11}$ workaholics experience worse psychological health.

\subsection{Workaholism and Work-Family Conflict}

Oates $^{12}$ emphasized that similar to alcoholics, workaholics also experience illhealth, lack of delight and strained

*Author for correspondence 
relationships with others. Porter ${ }^{13}$ exposed the adverse impacts of workaholism. According to Bakker ${ }^{14}$ workaholics experience more work-family conflicts than others. Robinson ${ }^{15}$ confirmed that the workaholics are less caring for the spouse. Snir and Harpaz ${ }^{16}$ exposed the negative impacts of workaholism on children in the family. Barling et al., ${ }^{17}$ confirmed the association between workaholism and marital dissatisfaction. According to Brady et al., ${ }^{18}$ in terms of work-family conflict, workaholics differed from non-workaholics. Greenhaus and Beutell ${ }^{19}$ concluded that pressures from work and family contradict with each other. According to Hobfoll ${ }^{20}$ executing family role is more tedious for workaholics. Newaz and Zaman ${ }^{21}$ brought to the fore the state of work-life balance among bank employees in Bangladesh. Ayesha ${ }^{22}$ probed the impact of work-family conflict among female teachers in Bangladesh. Akanji ${ }^{23}$ analysed the existence of work-life conflicts and confirmed its prominence among employees of the service sector in Nigeria. Akanji ${ }^{24}$ exposed the actuality of the job stress and the ways to cope with in Nigeria call centres. However, the present study aims to analyse the Workaholism and the resulting health, family and social issues among project and team leaders of IT companies in the select cities of Tamil Nadu.

\section{Objectives}

- To study the factors influencing the respondents towards workaholism.

- To identify the workaholic behaviour among the respondents.

- To analyze the relationship between workaholic behaviours and the health issues.

- To analyze the relationship between workaholic behaviours and family and social issues.

\section{Methodology}

\subsection{Sampling Procedure}

The study is based on primary data collected by administering the interview schedule. Multi stage random sampling technique was adopted to select the sample. In the first stage, five cities were selected as the sample areas namely, Madurai, Trichy, Coimbatore, Salem and Chennai. In the second stage, from every city chosen, the project and team leaders were selected in particular. In total, 500 sample respondents were approached to collect the data from the entire selected five cities. But out of 500 respondents approached, only 118 responses were found fully completed and eligible for analysis. Hence the total sample size finally confined to 118 IT project and team leaders as shown in Table 1.

Necessary secondary data were also collected relating to the workaholic behaviour from journals, magazines and newspapers including e-resources.

\subsection{Tools of Analysis}

Data were classified into appropriate tables and analysed using SPSS 17.0 software package. The statistical tools employed were Mean, Standard Deviation, Friedman Rank Test and Correlation Analysis.

\subsection{Hypotheses of the Study}

$\mathrm{H}_{\mathrm{o}}$ : There is no significant relationship between workaholic behaviour and health issues.

$\mathrm{H}_{\mathrm{o}}$ : There is no significant relationship between workaholic behaviour and that of family and social issues.

\section{Analysis and Interpretation}

Friedman Test was used to analyse the factors influencing towards workaholism and Descriptive Statistics was used to find the workaholic behaviour among the respondents. Correlation Analysis was used to find the relationship between workaholic behaviour and the health, family and social issues.

\subsection{Analyzing the Factors Influencing the Respondents towards Workaholism}

Friedman test was used to find the most influencing factor towards an employee becoming workaholic. The resultant mean ranks were found with reliability.

It could be noted from the Table 2 that among the various factors influencing the respondents towards workaholism, 'Fear of losing the job' was ranked first, followed by 'Vigour of on-time work completion', 'First mover and appreciation' and 'Liking towards recognition and appreciation'. The least of all the factors was 'Self motivated and competitive in nature' and the reliability is 0.68 .

Table 1. Distribution of sample respondents

\begin{tabular}{lcc}
\hline Sl. No & Cities & Total No. of Respondents \\
\hline 1 & Madurai & 22 \\
2 & Trichy & 24 \\
3 & Coimbatore & 26 \\
4 & Salem & 20 \\
5 & Chennai & 26 \\
Total & & 118 \\
\hline Source: Primary Data &
\end{tabular}

HuSS: International Journal of Research in Humanities and Social Sciences 
Table 2. Friedman test showing the most influencing factor towards workaholism

\begin{tabular}{lcccc}
\hline Influencing Factors & Mean & SD & Mean Rank & Reliability \\
\hline Fear of losing the job & 4.57 & 0.94 & 3.83 & 0.68 \\
Vigour of on-time work completion & 3.75 & 1.08 & 3.76 & \\
First mover and appreciation & 3.79 & 0.92 & 3.72 & \\
Liking towards recognition and appreciation & 3.26 & 1.38 & 3.24 \\
Self-motivated and competitive in nature & 2.76 & 1.43 & 2.75 & \\
\hline Source: Computed from Primary Data & & &
\end{tabular}

Table 3. Workaholic behaviour among the respondents

\begin{tabular}{lccc}
\hline Workaholic Behaviour & $\mathrm{N}$ & Mean & SD \\
\hline Spend sleepless nights & 118 & 10.39 & 2.172 \\
Feel like working is the ultimate aim of Life & 118 & 10.08 & 2.149 \\
Like being off the family and social activities & 118 & 9.87 & 2.330 \\
Spend long hours in work-related activities & 118 & 10.53 & 2.395 \\
\hline Source: Computed from Primary Data & & &
\end{tabular}

\subsection{Identifying the Workaholic Behaviour among the Respondents}

To identify the workaholic behaviour among the respondents, descriptive statistics was carried out to find the mean and standard deviation. The workaholic behaviour that were selected for the study includes 'Spending sleepless nights,' 'Feel like working is the ultimate aim of life,' 'Like to be off the family and social activities' and 'Spending long hours in work-related activities'.

It is evident from Table 3 that in case of the respondents' workaholic behaviour, 'Spending long hours in work-related activities' is the most primary factor with a mean 10.53 and std. deviation 2.395 and the next factor is 'Spending sleepless nights' with a mean 10.39 and std. deviation 2.172. The next two factors- 'Feel like working is the ultimate aim of life' and 'Like to be off the family and social activities' have registered mean scores of 10.08 and 9.87, and std. deviations of 2.149 and 2.330 respectively. This clearly exposes the respondents' attitude of mainly spending long hours in work related activities. Hence, the sample respondents are addicted to workaholism.

\subsection{Relationship between Workaholic Behaviour and Health Issues}

Correlation analysis is carried out to find the relationship between the workaholic behaviour and Health issues of the respondents. The following null hypothesis is framed:

$\mathrm{H}_{0}$ : There is no significant relationship between workaholic behaviour and health issues.
Table 4 explains the relationship between the two variables.

It is evident from Table 4 that the correlation among all the explanatory variables is highly significant and positive, which means that the workaholic behaviour is highly significantly and positively correlated with the respondents' health issues. Hence, the null hypothesis that there is no significant relationship between workaholic behaviour and health issues is disproved.

\subsection{Relationship between Workaholic Behaviour and Family and Social Issues}

Correlation analysis is carried out to find the relationship between the workaholic behaviour and family and social issues of the respondents. The following null hypothesis is framed:

$\mathrm{H}_{0}$ : There is no significant relationship between workaholic behaviour and family and social issues.

Table 5 explains the relationship between the two variables.

It can be noted from Table 5 that the correlation among all the explanatory variables is highly significant and positive, which means that the workaholic behaviour is highly significantly and positively correlated with the respondents' family and social issues. Hence, the null hypothesis that there is no significant relationship between workaholic behaviour and family and social issues is disproved. 
Table 4. Relationship between workaholic behaviour and health issues (correlation)

\begin{tabular}{|c|c|c|c|c|c|}
\hline Factors & Test/Sig. & $\begin{array}{c}\text { Getting } \\
\text { physically } \\
\text { exhausted }\end{array}$ & $\begin{array}{c}\text { Mentally } \\
\text { pressurized \& } \\
\text { Stressed }\end{array}$ & $\begin{array}{l}\text { Distress and depression } \\
\text { happens if work is not } \\
\text { completed on time }\end{array}$ & $\begin{array}{l}\text { Spending sleepless } \\
\text { nights leading to } \\
\text { physical illness }\end{array}$ \\
\hline \multirow[t]{3}{*}{$\begin{array}{l}\text { Spend long hours in } \\
\text { work-related activities }\end{array}$} & $\begin{array}{l}\text { Pearson } \\
\text { Correlation }\end{array}$ & $.772^{\star *}$ & $.715^{\star *}$ & $.786^{* *}$ & $.656^{* *}$ \\
\hline & Sig. (2-tailed) & .000 & .000 & .000 & .000 \\
\hline & $\mathrm{N}$ & 118 & 118 & 118 & 118 \\
\hline \multirow[t]{3}{*}{ Spend sleepless nights } & $\begin{array}{l}\text { Pearson } \\
\text { Correlation }\end{array}$ & $.765^{\star *}$ & $.718^{\star *}$ & $.573^{\star *}$ & $.645^{\star \star}$ \\
\hline & Sig. (2-tailed) & .000 & .000 & .000 & .000 \\
\hline & $\mathrm{N}$ & 118 & 118 & 118 & 118 \\
\hline \multirow[t]{3}{*}{$\begin{array}{l}\text { Feel like working is the } \\
\text { ultimate aim of Life }\end{array}$} & $\begin{array}{l}\text { Pearson } \\
\text { Correlation }\end{array}$ & $.738^{\star *}$ & $.641^{\star *}$ & $.553^{\star *}$ & $.641^{* *}$ \\
\hline & Sig. (2-tailed) & .000 & .000 & .000 & .000 \\
\hline & $\mathrm{N}$ & 118 & 118 & 118 & 118 \\
\hline \multirow[t]{3}{*}{$\begin{array}{l}\text { Like being off the family } \\
\text { and social activities }\end{array}$} & $\begin{array}{l}\text { Pearson } \\
\text { Correlation }\end{array}$ & $.716^{\star *}$ & $.756^{\star \star}$ & $.790^{\star *}$ & $.480^{\star *}$ \\
\hline & Sig. (2-tailed) & .000 & .000 & .000 & .000 \\
\hline & $\mathrm{N}$ & 118 & 118 & 118 & 118 \\
\hline
\end{tabular}

Source: Computed from Primary Data

Table 5. Relationship between workaholic behaviour and family and social issues

\begin{tabular}{|c|c|c|c|c|c|}
\hline Factors & Test/Sig. & $\begin{array}{l}\text { Not spending } \\
\text { adequate time } \\
\text { with family }\end{array}$ & $\begin{array}{c}\text { Less attachment } \\
\text { with spouse and } \\
\text { Children }\end{array}$ & $\begin{array}{c}\text { Facing marital } \\
\text { problems leading } \\
\text { to Divorce }\end{array}$ & $\begin{array}{l}\text { Weak social } \\
\text { relations }\end{array}$ \\
\hline \multirow[t]{3}{*}{$\begin{array}{l}\text { Spend long hours in } \\
\text { work-related activities }\end{array}$} & $\begin{array}{l}\text { Pearson } \\
\text { Correlation }\end{array}$ & $.882^{\star *}$ & $.715^{* *}$ & $.769^{* *}$ & $.675^{\star *}$ \\
\hline & $\begin{array}{c}\text { Sig. } \\
\text { (2-tailed) }\end{array}$ & .000 & .000 & .000 & .000 \\
\hline & $\mathrm{N}$ & 118 & 118 & 118 & 118 \\
\hline \multirow[t]{3}{*}{ Spend sleepless nights } & $\begin{array}{l}\text { Pearson } \\
\text { Correlation }\end{array}$ & $.675^{\star *}$ & $.817^{\star *}$ & $.548^{* *}$ & $.681^{* *}$ \\
\hline & $\begin{array}{c}\text { Sig. } \\
\text { (2-tailed) }\end{array}$ & .000 & .000 & .000 & 000 \\
\hline & $\mathrm{N}$ & 118 & 118 & 118 & 118 \\
\hline \multirow[t]{3}{*}{$\begin{array}{l}\text { Feel like working is } \\
\text { ultimate aim of Life }\end{array}$} & $\begin{array}{l}\text { Pearson } \\
\text { Correlation }\end{array}$ & $.681^{\star *}$ & $.615^{* *}$ & $.562^{\star \star}$ & $.625^{*}$ \\
\hline & $\begin{array}{c}\text { Sig. } \\
(2 \text {-tailed })\end{array}$ & .000 & .000 & .000 & 000 \\
\hline & $\mathrm{N}$ & 118 & 118 & 118 & 118 \\
\hline \multirow[t]{3}{*}{$\begin{array}{l}\text { Like being Off from } \\
\text { family \& social activities }\end{array}$} & $\begin{array}{l}\text { Pearson } \\
\text { Correlation }\end{array}$ & $.752^{\star *}$ & $.756^{*}$ & $.790^{* *}$ & $.580^{\star *}$ \\
\hline & $\begin{array}{c}\text { Sig. } \\
\text { (2-tailed) }\end{array}$ & .000 & .000 & .000 & .000 \\
\hline & $\mathrm{N}$ & 118 & 118 & 118 & 118 \\
\hline
\end{tabular}

Source: Computed from Primary Data 


\section{Conclusion and Suggestions}

The study has revealed that 'Fear of losing the job', followed by 'Vigour of on-time work completion' are the factors that are most influencing the respondents towards workaholism. 'Spending long hours in work-related activities' and 'Spending sleepless nights' are the other factors identified to be influencing towards the workaholic behaviour among the respondents. Further, it is found that there is a strong correlation between workaholic behaviour and health, family and social issues and hence the null hypotheses are rejected.

Human resources are the valuable assets of any organization. Organizations should volunteer to take efforts to maintain the well-being of its assets, which in turn would prove highly profitable both to the organization and the employees in the long run. To avoid workaholism among its employees, the IT companies need to take up the responsibility to avoid over loading and target fixing for the Team and Project Heads, that leads to stress and at last workaholic behaviour. The individual may even attempt to promote opportunities for recreation that restrict workpersonal life overlap. The company may also arrange for enforced vacations, development opportunities for better engagement or flexible roles and management training to facilitate enjoyment in the job. The companies may also attempt to organize yoga and meditation sessions during the working hours, which would enable the employees to get physical and mental health. Periodic assessments of work enjoyment at the workplace may assist in determining if workload needs to be adjusted.

\section{References}

1. Andreassen CS, Ursin H, Eriksen HR. The relationship between strong motivation to work. Workaholism and Health, Psychology and Health. 2007; 22:615-29.

2. Spence J, Robbins A. Workaholism: Definition, measurement, and preliminary results. Journal of Personality Assessment. 1992; 58:160-78.

3. Robinson BE. Workaholism: Bridging the gap between workplace, sociocultural, and family research. Journal of Employment Counseling. 2000; 37:31-47.

4. Nešpor K. Závislostnapráci. Praha: Grada Publishing; 1999.

5. Scott KS, Moore KS, Miceli MP. An exploration of the meaning and consequences of workaholism. Human Relations. 1997; 50:287-314.

6. Bonebright CA, Clay DL, Ankenmann RD. The relationship of workaholism with work-life conflict, life satisfaction, and purpose in life. Journal of Counseling Psychology. 2000; 47:469-77.
7. Schaufeli WB, Bakker AB, Van der Heijden FMMA, Prins JT. Workaholism, burnout and well-being among junior doctors: The mediating role of role conflict. Work and Stress. 2009; 23:155-72.

8. Taris TW, Geurts SAE, Schaufeli WB, Blonk RWB, Lagerveld SE. All day and all of the night: the relative contribution of two dimensions of workaholism to well-being in selfemployed workers. Work and Stress. 2008; 22:153-65.

9. Kubota K, Shimazu A, Kawakami N, Takahashi M, Nakata A, Schaufeli WB. Association between workaholism and sleep problems among hospital nurses. Industrial Health. 2010; 48:864-71.

10. Schaufeli WB, Taris TW, Van Rhenen W. Workaholism, burnout, and engagement: Three of a kind or three different kinds of employee well-being. Journal of Applied Psychology: An International Review. 2008; 57:173-203.

11. Shimazu A, Schaufeli WB. Is workaholism good or bad for employee well-being? The distinctiveness of workaholism and work engagement among Japanese employees. Industrial Health. 2009; 47:495-502.

12. Oates W. Confessions of a workaholic: The facts about work addiction. New York: World; 1971.

13. Porter G. The organizational impact of workaholism: Suggestions for researching the negative outcomes of excessive work. Journal of Occupational Health Psychology. 1996; 1(1):70-84.

14. Bakker AB, Demerouti E, Burke R. Workaholism and relationship quality: A spillover-crossover perspective. Journal of Occupational Health Psychology. 2009; 14:23-33.

15. Robinson BE, Flowers C, Carroll J. Work stress and marriage: A theoretical model examining the relationships between workaholism and marital cohesion. International Journal of Stress Management. 2001; 8:165-75.

16. Snir R, Harpaz I. Attitudinal and demographic antecedents of workaholism. Journal of Organizational Change Management. 2004; 17:520-36.

17. Barling J, Bluen S, Moss V. Type a behavior and marital dissatisfaction: Disentangling the effects of achievement striving and impatience-irritability. Journal of Psychology. 1990; 124:311-9.

18. Brady BR, Vodanovich SJ, Rotunda R. The impact of workaholism on work-family conflict, job satisfaction, and perception of leisure activities. The Psychologist-Manager Journal. 2008; 11:241-63.

19. Greenhaus JH, Beutell NJ. Sources of conflict between work and family roles. Academy of Management Review. 1985; 10:76-88.

20. Hobfoll SE. Social and psychological resources and adaptation. Review of General Psychology. 2002; 6:307-24.

21. Newaz MT, Zaman KF. Work-life balance: Is it still a new concept in private commercial banking sector of Bangladesh? International Journal of Research Studies in Management. 2012 Oct; 1(2):57-66. Available from: www.consortiacademia.org 
22. Ayesha T. The impact of social support on work-to-family and family-to-work conflict: An analysis on the female primary school teachers of Bangladesh. International Journal of Research Studies in Management. 2012 Oct; 1(2):67-78. Available from: www.consortiacademia.org

23. Akanji BO. An exploratory study of work-life balance in Nigeria: Employees' perspectives of coping with the role conflicts. International Journal of Research Studies in Management. 2013 Oct; 2(2):89-100. Available from: www. consortiacademia.org

24. Akanji BO. A case study on occupational stressors and effective stress management interventions from a call center perspective. International Journal of Research Studies in Management. 2016 Oct; 5(2):13-24. Available from: www. consortiacademia.org

\section{Other References}

1. Schaufeli WB, Taris TW, Bakker AB. Dr Jekyll and Mr Hide: On the differences between work engagement and workaholism. Work Hours and Work Addiction. 2016; 193-252.

2. Schaufeli WB, Taris TW, Bakker AB. It takes two to tango. Workaholism is working excessively and working compulsively. The long work hours culture: Causes, consequences and choices; 2008. p. 203-226.

3. Taris TW, Schaufeli WB, Verhoeven LC. Workaholism in the Netherlands: Measurement and implications for job strain and work-nonwork conflict. Applied Psychology: An International Review. 2005b; 54:37-60. 